This article is available open access under a CC BY 4.0 license as part of Berghahn Open Anthro, a subscribe-to-open model for APC-free open access made possible by the journal's subscribers.

\title{
TOWARD AN EPIDEMIOLOGY OF RITUAL CHANTS
}

Pierre Déléage

Translated by Matthew Carey

\begin{abstract}
This article develops an epidemiological approach to the analysis of ritual discourse, comparing three distinct genres of Amazonian ritual chants: Wayana, Sharanahua, and Ingarikó. The aim is not to identify the inherent properties of chants, nor to establish ideal types of ritual context (initiation, shamanism, prophetism), but to analyze the different factors affecting the stabilization of the heterogeneous elements of ritual traditions. First, I identify the different procedures (order transfer, parallelism, intersemioticity, and inscription) that stabilize content. Then, assuming that the spread of ritual chants depends on an institutional apparatus, I explore the chants' rules of distribution and the types of legitimizing authority involved. Finally, I show how the combined analysis of these different factors offers us a new way of understanding ritual innovation.
\end{abstract}

Keywords: Amazonia, Ingarikó, oral traditions, prophetic movements, ritual discourse, shamanism, Sharanahua, Wayana

October 1964. Tiliwe village on the Upper Maroni river, French Guyana. Palanaiwa, a Wayana chief, decides to organize a major initiation ritual known as a maraké. Opoja, chief of a neighboring village called Tipïti, accepts the invitation. The two communities then pool their efforts and conduct the four-month ceremony together. Several young men and two girls are of the age to undergo this obligatory initiation. Henceforth, they are to respect a number of taboos: they must avoid a long list of foodstuffs, abstain from all sexual activity, stay away from fire, and avoid casting stones into the river. Dances are held at regular intervals, and the novices are obliged to participate. The two villages come together for these dances, donning their most beautiful apparel and consuming 
large quantities of manioc beer, which they vomit up periodically. Former initiates dance until they drop and improvise songs, especially those known as kanawa and maipuli, which describe the virtues of manioc beer. Kuliamann, a well-regarded ritual specialist, also sings a long kalawu chant, which includes a precise description of the different stages of the initiation ritual.

After a period of reclusion away from the village, the neophytes are loaded with fineries, and the initiation reaches its apogee. They are whipped and forced to dance without pause, despite their exhaustion. Their heads are shaved and their bodies covered with larges frames depicting venomous ants and wasps. Most of them pass out, and the next morning, when they awake, they have become initiates (Hurault 1968: 87-106).

May 2002. Gasta Bala village, on the Purus river, Peru. Padisha, a young Sharanahua girl, experiences a sudden fever for the second time in a week. She is ill but does not know exactly what is wrong. She has already radically altered her diet and gone to the village clinic in search of drugs, but the fever persists. Her sister advises her to consult a shaman named Picha. In the end, Picha comes to see her, and after a brief discussion they decide to conduct a therapeutic ritual the next day. When night falls, the patient is told to lie down in one of the hammocks in the shaman's house. Picha sits opposite her in his own hammock. He lights his pipe, inhales, then stands up and blows staccato billows of tobacco smoke over the young woman's joints. He then sits back down, closes his eyes, and begins to recite several coshoiti chants. These last for several hours, interrupted only by periodic fumigations. The chants describe the origin of the various pathogenic agents responsible for the young woman's illness and are indispensable to the ceremony. Without them, she cannot be cured. When the patient falls asleep, she is carried home, and the ritual comes to an end (Déléage 2009a).

February 1993. Serra do Sol village, on the Igarapé river, Brazil. An Ingarikó ritual specialist oversees an 'alleluia ceremony'. The faithful are gathered in the village church, where they sit in the pews and listen to the 'pastor' eloquently preach about the future coming of the Messiah and the villagers' transformation into white men (and women). After the sermon, the participants begin to dance, first in semi-circles and then in rows. They make slow, repetitive movements in mechanical unison. But little by little, and almost imperceptibly, the dance speeds up, and the movements become more disjointed. Throughout the dance, the participants repeat the alleluia chants-standard appeals to the Messiah handed down from a nineteenth-century prophet and perfectly memorized by all. Once exhausted, they kneel together for a final prayer and share a meal (Azevedo de Abreu 2004: 75-85).

Chants or songs play a central role in each of these quite different Amazonian rituals: the Wayana ceremony allows participants to improvise kanawa and maipuli songs, while a specialist declaims the long kalawu chant; Sharanahua shamanic healing features long coshoiti chants; and the Ingarikó 
millenarians dance and sing their alleluia chants. This article explores those aspects of the ritual discourse that are transmitted or handed down. How are they learned? Why do the singers choose to learn and hand them down? In short, how have these ritual chants and processes of transmission become stabilized in these predominantly oral societies?

These questions partake of an epidemiological vision of culture (Sperber 1996; Sperber and Hirschfeld 2004). The transmission of information and practices is a constant part of social existence, but most of these processes are restricted to the local context of their production. Some of them (which we often refer to as 'traditional'), however, are more frequently and more faithfully transmitted than others, either by being stabilized in broadly similar form over a number of generations, or because they invade a large part or indeed all of a society. Such practices and information become traditional only insofar as they are better able to resist the inevitable distortions inherent in the multiple processes of acquisition, memorization, inference, and communication through which they pass. In other words, traditional practices or ideas form but a small part of the vast array of things that are conceived of and communicated. These processes of selection and stabilization in relatively standard form rely on a number of factors. If it is to resist the transformations that can occur during transmission, information must be salient in its particular surroundings, easily communicated, and easily memorized.

Whereas the epidemiology of culture explores the whole array of psychological and environmental reasons behind the stabilization of cultural phenomena in general, this article analyzes one particular phenomenon: Amazonian ritual chants. In so doing, it leaves to one side the most general cognitive and ecological factors, such as demographics and modes of subsistence, and looks instead at factors more specifically relevant to ritual chants and their cultural context. These factors are themselves cultural elements that could also explain psychological and environmental factors in terms of higher order, but the article addresses them only in passing. Its central aim is to identify and evaluate certain stabilizing factors of ritual chants in the oral transmission of tradition, and for this reason the focus is on Amazonian examples.

The article begins by situating ritual chants vis-à-vis other forms of traditional discourse before moving on to identify the procedures-order transfer, parallelism, intersemioticity, and inscription-that can be used to stabilize the content of these chants. Taking as given that the transmission of these chants is inseparable from their position within an institution, the article then proceeds to explore the manner in which institutional rules influence the stabilization and propagation of these cultural phenomena. It focuses particularly on the rules governing the distribution of chants and on the ways in which the attribution of authority legitimates their transmission. Finally, it shows how an epidemiological approach opens up new avenues for understanding ritual innovation. 


\section{Traditional Discourses and Memory}

\section{Myths}

Contemporary Amazonian myths normally consist of short narratives describing the origins of people and their customs, or anecdotes involving animals and humans. These narratives are transmitted in contexts very similar to everyday communication. The narrator is typically an older person who tells myths to a younger audience, often at nightfall. It is here that the process of transmission occurs: the myths are not learned outside of these occasions, and it is more a matter of assimilating the content than the exact wording. The memorization of myths should therefore be seen as a process of reconstruction during which their stability is principally constrained by the interaction between universal psychological factors and various aspects of the natural and cultural environment. These factors affect all aspects of culture, especially traditional discursive forms, and are in no way specific to myths. The following is the beginning of a Sharanahua myth as related to me during fieldwork:

It is told that long ago there lived a woman. She had been pregnant for two years, but could not give birth. The baby in her womb could already talk. One day she said to herself: "I shall go to visit my brothers." And off she went. On the way, whenever she saw some pretty flowers, the baby would say: "Mother, pick me that flower." And so she picked all sorts of flowers. In one flower there was a wasp's nest. The baby said: "Pick me that pretty flower." So she picked the flower and the wasp stung her before flying away. "When will you leave my womb?" asked the woman. "If you came out, I'd do everything you ask," she shouted in anger and smacked her stomach. The baby cried and wriggled around, but the woman kept on walking. She reached a crossroads where one path led to the Jaguar People and the other to her brothers' village. "My son," she asked, "which path leads to your uncles' village?" But the baby was angry at having been smacked and refused to answer. And so the woman took the path that led to the Jaguar People.

Most Amazonian myths feature a number of counter-intuitive actions or interactions that anchor other, more mundane exchanges. In an ontological context where all the characters are capable of speech and move and socialize like humans, some of them (often those who bear the name of a well-known animal) behave counter-intuitively, either by flying, roaring, or living underwater (like the animal whose name they share), or by shapeshifting and carrying out magical acts. In the example above, there is one massively counter-intuitive act (a baby who speaks from the womb) and a number of standard motherchild interactions. Later on, the jaguars behave just like humans, despite certain aspects of their physical characteristics (e.g., their canines) and behavior 
(they devour the mother). This combination of minimal counter-intuitivity interrupting maximal intuitivity makes these narratives more memorable than others and fixes them as long as the environment of their enunciation remains more or less constant (Boyer 2001).

It is well known that myths change over time. Each new narrative act introduces variation, not only because of the intrinsic limits of human memory, but also because myths are learned schematically (Bartlett 1932). Additionally, they change when incorporating elements that have only recently appeared in the surrounding environment-such as white people, metal, outboard motors, or writing. Numerous studies have shown how these thematic innovations remain encompassed within robust narrative schemas, either by replacing similar elements or by slotting into a predetermined place (see, e.g., Albert and Ramos 2002; Fausto 2002). In both cases, the long-term stability of narrative content is widely recognized. ${ }^{1}$

\section{Ritual Chants}

The ritual discourses that concern us here share a high degree of formalization. Maurice Bloch (1974: 60) has outlined the typical characteristics of such formalized genres: fixed sonority, a drastically limited range of intonation, the exclusion of numerous syntactic possibilities, restricted vocabulary, rigid sequentiality, and stylistic rules that apply to all levels of such discourse. These formalized discourses can fall anywhere along a continuum ranging from those whose narrative content is improvised at each different act of enunciation to those whose content must remain as fixed as possible. In the former case, it is the technique of discursive formalization that remains fixed and that is therefore transmitted, while in the latter, the entire discourse must, as far as possible, be pronounced word for word (Fausto et al. 2011). Were one to appeal to the slightly reductive language of psychology, one might say that the first discursive genre requires only procedural memory, whereas the second requires verbal memory, which involves both schematic and procedural memory. ${ }^{2}$

In some cases, then, what is transmitted is simply a technique of formalization applicable to all discourses associated with particular, contextually determined themes. Each new incarnation of the discourse is seen as the original creation of its narrator. The Wayana's kanawa and maipuli chants are good examples of partly improvised songs that belong to a particular ritual genre by virtue of their adhering to a predetermined form. They are sung when members of different villages gather together: the hosts sing maipuli, while the guests sing kanawa. The two genres differ in terms of melody, prosody, their name, and their singer (host or guest). Their content varies at each new act of enunciation and consists of variations on the theme of the delights of manioc beer. What is transmitted in these chants is not their precise content, but a 
melodic and poetic form attached to a simple theme. They are a commentary on ritual festivities that take a musical form.

There are, however, numerous ritual discourses that must, so far as possible, be repeated verbatim-that is, encoded in verbal memory. Jack Goody (1987) distinguishes between two types of discursive learning: 'generative recall', typical of oral societies, and 'verbatim memorization', characteristic of literate societies. It is clear that in an Amazonian context, where the transmission of traditional discourse is essentially oral, all acts of memorization are more or less reconstructive. Such grandiose typological dualisms, for all their heuristic value, are therefore not of overriding interest to us here. I intend to focus instead on the internal variations within reconstructive memory. It appears that some forms of discourse tend to involve more properly verbal memorization than others, requiring the fixing of both narrative content and the actual words pronounced.

If a Sharanahua wishes to become a shaman, he must undergo an initiation ritual. One of the key episodes of this rite is a hallucinogenically inspired vision. Surprisingly, the content of these visions is extremely standardized, and all apprentice shamans see more or less the same thing. Indeed, the future vision's content is communicated to the apprentice by an experienced shaman, who establishes the limits of the visionary experience. This process of transmission occurs in two distinct ways: on the one hand, the shaman simply recounts his own initiatory vision; on the other, the novice must learn by heart a number of highly formalized chants (rabi) that are descriptions of visions. The content of these vision narratives and rabi chants is extremely similar and describes a series of encounters between shamans and tutelary spirits. The latter are variously described as birds, serpents, and warriors. They fly, poison novices, and shoot them full of arrows, or they feed them, paint their bodies, and even teach them songs. The two distinct genres tell identical tales: the first in prose form, requiring schematic memory, and the second in an extremely formalized manner that relies on verbal memory. This difference at the level of memorization has clear effects: rabi chants are far less changeable than vision narratives. While the latter have incorporated new elements from the changing environment (mestizo soldiers, rifles, helicopters, traders, radios, etc.), ritual chants have resisted all such innovation (Déléage 2009a: 154-159).

We can see that formalized ritual discourses are situated between two extremes: one requires only procedural memory in order to stabilize a range of formal techniques, while the other combines schematic memory of semantic content with procedural memory of formal invariants in order to allow for almost verbatim memorization. As perfect stability is of course unattainable, here we are discussing relative degrees of medium-term stabilization. We can then distinguish ritual discourses from other traditional discourses in terms of the type of memory required (schematic, procedural, or verbal) and the type 
of stability desired (long-term schematic or medium-term verbatim). That said, as the same narrative content is often shared by different sorts of discursive genres, one might say that they mutually stabilize one another at the level of content. So the Wayana's kalawu chants contain precise descriptions of numerous initiation ritual sequences and sections of myths, while the Sharanahua's coshoiti chants sometimes incorporate whole myths (Déléage 2010a) or detailed descriptions of plants and animals drawn from everyday knowledge. Alleluia songs, meanwhile, relay the message of a late-nineteenth-century Macuxi prophet. In each case, the ritual chants transmit little new information, merely applying formal discursive techniques to knowledge that has already been relayed by other means. One does not need to memorize or understand kalawu chants in order to know the different stages of Wayana initiation. Most people know both the myths contained in kalawu and coshoiti and the Macuxi prophecy. In other words, the content of these ritual discourses has already been stabilized outside the ritual context, although the ritual reiteration of this content serves to further stabilize mythical narratives and ritual sequences. Myths and ritual discourses and ritual behavior and ritual discourses co-stabilize each other. Because the ritual chants under discussion here aim for verbatim transmission, they employ vastly more stabilizing techniques than other forms of traditional discourse. The following section identifies and explores some of these techniques.

\section{Techniques for Stabilizing Ritual Chants}

The different techniques employed to increase the medium-term verbatim stability of ritual chants are not always consciously deployed by those who transmit the chants. As these techniques are to be found in most ritual discourses that require word-for-word transmission, it is fair to assume that their presence is an effect of procedures of verbatim transmission. With the exception of the modes of writing, these techniques are not used to stabilize chants; on the contrary, the chants have been formalized by cognitive techniques precisely because they have been selected and stabilized.

One of the principal stabilization techniques present in oral traditions is what I call 'order transfer'. All ritual discourses are constrained in terms of the diachronic ordering of their different elements. The simplest form of this ordering is probably the enumeration of lists of names. For instance, the kalidzamai chants of the Rio Negro Baniwa are structured around lists of toponyms: "Hills of Animal-Spirit Hair," "Place of Poison," "Places of Animal-Spirit Houses," "Bee-Spirits' Houses," "Place of Honey," and “Clear Day Places” (see Wright 1993). As such, they constitute mental maps of the river's course, and the memorization of the ordering of the chant's different elements relies on 
cartographic knowledge that may have been acquired long before in non-ritual contexts. This form of order transfer is present in numerous ritual discourses. The chant is often structured by a form of spatial ordering, as is the case among many societies of the Upper Rio Negro, or it may appeal to genealogy, as with the Amuesha (Smith 1977) or the Ayoreos (Bessire 2011): in each case, order transfer helps to stabilize the chants' structure. The 'gaps' between names can be filled either by specific statements, which may convey further descriptive or narrative details linked to the names, or by the tireless repetition of particular phrases-that is, parallelism.

Parallelism is very common in oral traditions (Finnegan [1977] 1992). Kalawu chants, for instance, use it as a means of structuring content. The second sequence of this chant is a good example of the productivity of such techniques (Chapuis and Rivière 2003: 951):

You Pëlitëli, gather up the sauce pot, You Pëlitëli, gather up the sauce pot, You Majakale, gather up the sauce pot, You Majakale, gather up the sauce pot, You Mosile, gather up the sauce pot, You Mosile, gather up the sauce pot, Place it on the leaf-roofed kumu house, Place it on the leaf-roofed kumu house, Place it on the leaf-roofed pëwilipi house, Place it on the leaf-roofed pëwilipi house, Place it on the leaf-roofed wapu house, Place it on the leaf-roofed wapu house, Place it on the leaf-roofed ubim house, Place it on the leaf-roofed ubim house, Place it next to the wajha, Place it next to the wajha, Your sauce is all gone, dried up, Your sauce is all gone, dried up, You have emptied, cleaned out the tukawa pot, You have emptied, cleaned out the tukawa pot, You have emptied, cleaned out the ëliwë pot, You have emptied, cleaned out the ëliwë pot.

Ordered lists of names are embedded in repetitive phrases. This is both a fundamental principle of mnemonic economy and a structure that by virtue of its omnipresence in sung traditions must necessarily appeal to universal cognitive constraints. The Sharanahua's shamanic coshoiti chants also make use of parallelism to organize and stabilize content. The chants are composed of heptasyllabic lines structured by the same melody, with their basic linear unity arranged around the naming of the pathogenic spirit responsible for the patient's illness. 
The name is uttered in an esoteric language ideally known only to initiated shamans. For instance, the spirits of a hallucinogenic liana plant (ayahuasca) are called "the shuahua serpent's tail." These substitutions are typically based on a linear model of type XYZ + suffix, where X, Y, and Z are the elements of an esoteric name for the pathogenic spirit. This line is then repeated with variations in one of the elements or the suffix, and then followed by another line that takes up the esoteric name in reduced or pronominal form and associates it with a verb describing one of its typical activities, for example, lianas "pass from tree to tree." Most of the time, the verb makes sense for both of its potential subjects: the literal one (shuahua serpent) and the esoteric one (lianas). Finally, a third line excludes the name but retains the verb, incorporating it into a standard formula whose meaning is often fairly obscure but which refers to the origins of this activity. This gives rise to a line composed of verb + formula, for instance, "they began to pass from tree to tree." This basic structure is then applied, with variations, to some of the pathogenic spirit's morphological or ethological characteristics:

\section{Yohuu fachi uhua-nu Great sorcerer eggs (XYZ + suffix) \\ Arasi shoco-di \\ They have taken shape (pronoun + verb + suffix) \\ Shoco-tauihuahuadi \\ They have begun to take shape (verb + formula)}

These lines refer to ayahuasca seeds (great sorcerer eggs), which little by little grow into lianas. Even though all coshoiti chants share certain invariable sections, their distinctive core is constructed by the parallelistic integration of a long list of pathogenic spirits and their specific attributes (Déléage 2009a). The quasi-automatic nature of this parallelistic formalization facilitates memorization and encourages verbal stability. It also has the advantage of offering a predetermined form that can incorporate new content, although a full discussion of this process is beyond the scope of this article (see Déléage 2009b: 81).

Numerous rituals combine chants with various other forms of expression: musical instruments, dance, artifacts, and the spatial and chronological settings of the ritual. These forms of expression, which together constitute the ritual discourse's cultural niche, are each the object of particular learning processes. Sometimes these processes are temporally distinct from the learning of chants, but in any case they appeal to quite distinct mnemonic capacities. They are all, however, intersemiotically connected to ritual chants, which increases their stability. Thus, maipuli chants, for example, are systematically associated with particular dance steps and musical instruments. Another better-known example is the tule ceremonies of the Wayãpi of French Guyana, which involve the performance of between 10 and 40 named pieces pertaining to particular suites chosen from a vast repertoire. For instance, the Dung Beetle suite (see Beaudet 1983: 171-187) contains the following 16 separate pieces: 


$\begin{array}{ll}\text { Anilasekelelu } & \text { bat } \\ \text { Makwasili } & \text { bird } \\ \text { Yuwe } & \text { frog } \\ \text { Kwata } & \text { spider monkey } \\ \text { Anilayu } & \text { bat } \\ \text { Suwi } & \text { partridge } \\ \text { Tuluwa } & \text { (beer) pot } \\ \text { Pilipiliya } & \text { Wayana word } \\ \text { Palawa } & \text { parrot } \\ \text { Waliwowo } & \text { tree } \\ \text { Paipayo } & \text { bird } \\ \text { Yakami pialolo } & \text { brace of birds } \\ \text { Yakami } & \text { agamid } \\ \text { Yakalepape } & \text { caiman claws } \\ \text { Yu'i } & \text { tree frog } \\ \text { Ka'i } & \text { capuchin monkey }\end{array}$

Each of these names corresponds to several different forms of expression: a chant, a tune played on a clarinet, and sometimes a mimetic dance or specific action. In each case, variable elements are embedded in a repetitive structure so that the range of content is parallelistically organized. Thus, the chants are typically arranged around the repetition of the name of the particular piece (Anilasekelelu, Anilayu, etc.) or of a short phrase containing this name (kwata palayko, "the spider monkeys swing by the tail"; suwi iapelawa, "the partridge has a striped back"). This name or phrase is bookended by a nonsense syllable (e.g., ten ten), which reappears in all subsequent chants. So the bat chant goes as follows: Anilasekelelu anilasekelelu ten ten anilasekelelu ten ten. The chant translated as "the spider monkeys swing by the tail" looks like this: Kwata palayko kwata palayko ten ten kwata palayko ten ten (Beaudet 1983: 176-177).

In the same way, each tune shifts between its specific 'signature' motif and another motif proper to the entire suite (Beaudet 1997). Finally, the ceremonial dance is arranged around a core rhythmic structure: a synchronized collective dance, it is performed in a circle. Each dancer leans forward with an instrument in his left hand and his right hand placed upon his neighbor's shoulder. This basic structure is common throughout the Amazon region. The structural core is then interspersed with variable dances related to the name of the specific piece, normally involving imitations of the eponymous animal's behavior (Beaudet 2010).

Thus, the Wayãpi's tule ceremony incorporates dance, music, and chants that share a common structure-the shift between variable elements (mimetic dance, piece-specific melody, and the sung name and constant elements (basic step, suite melody, and the syllables ten ten). The intersemioticity of these different aspects of the ritual stabilizes their respective content (Cesarino de Niemeyer 2011; Menezes Bastos 2007). 
The Teko of French Guyana perform a ceremony very similar to that of the Wayãpi, using an inscription technique to help memorize the order of the different pieces within a suite. The specialist in charge of the ritual sequentially attaches a number of objects representing the different pieces to a cotton thread (see fig. 1). These objects either take the form of one of the named animal's body parts (a bird's feather, a crab's claw, a tuft of peccary fur) or are figurative images engraved in balsa wood (e.g., a bird or a stool). Each object on the 'memory string' corresponds to a musical melody, a chanted name, and a particular dance-that is, to the variable section of each form of expression, as the invariable section has no need to be noted. The order of objects on the string allows for the memorization of their order of appearance within the ritual, similar to prayer or rosary beads (Déléage 2010c; Severi 2007).

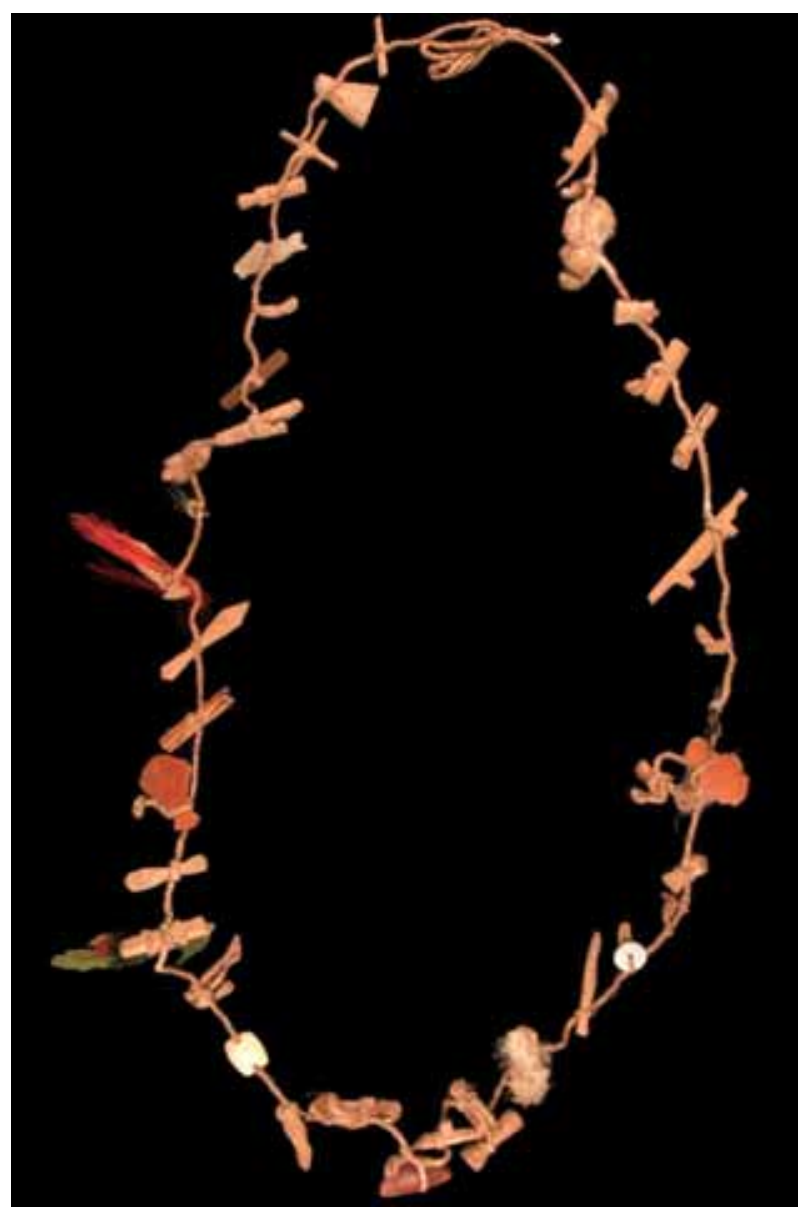

FiguRE 1: Teko 'rosary beads'. Source: Déléage (2010c: 176). Courtesy of L'Homme. 
The presence of this inscription technique in the ceremonies of an oral society allows us to re-examine Goody's (1987) distinction between two different types of memorization, and to see that while his sharp dualism holds more or less good, it occludes the fine detail of ritual transmission that makes it such an interesting object of study. The introduction of writing as an inscription technique for the transmission of ritual discourse has clearly had a major impact on the process-one that goes far beyond the probable initial aim of stabilizing ritual content in canonical form (Assmann 1992; Nagy 1996). However, writing is but one inscription technique among many, such as the Teko 'rosary beads', and these methods are themselves but one particular means of creating connections between different forms of ritual expression. All of these diverse techniques serve to stabilize the content of ritual discourse, aiding memorization. In other words, rather than establishing a sharp distinction between 'generative' and 'verbatim' memorization, we need to apply ourselves to measuring degrees of variability in the memorization of ritual discourse (which is always more or less 'generative') by taking into account the different techniques used to control these variations.

\section{Rules Concerning the Distribution of Ritual Chants}

Unlike most mythical narratives, ritual chants are inscribed within institutions, which allows them to aim for verbatim repetition through the deployment of content-stabilizing techniques. For the purposes of an epidemiological analysis of culture, we can define institutions as "a process of distribution of a set of representations, which is itself managed by representations belonging to this same set" (Sperber 1996: 104). For instance, although a mythical narrative may only spread by virtue of its internal properties that make it pertinent and therefore easily memorizable, it can nonetheless become an institution if the moment of recitation is constrained by a rule specifying that it can only be told in a particular context. In this case, the mythical narrative becomes an elementary form of institution: a ritual discourse. An example of this is the shamanic narratives discussed above that occur both in precise ceremonial contexts and in informal everyday ones.

A ritual institution can be defined as a set of rules governing the transmission of particular ritual elements (gestures, artifacts, chants, etc.). The number and nature of these rules depend, of course, on the institution. Here, we look at the effect of such rules on ritual chants. In the institutions that concern us, the principal rules concern the proper context of the enunciation of such chants (when and where), their distribution (who can perform them), and the processes of determining the authority that gives performers a reason to repeat the chants (why). Each of these rules of transmission has precise effects on 
the chants' stability: they affect the quality of memorization, the quantity of chants remembered, and the type of memorization process employed. These institutional rules, just like ritual chants, are cultural facts that are themselves transmitted and stabilized-and like ritual chants, they are transformed in the process. This article touches only briefly on rules of occurrence (when and where chants can be performed) for the simple reason that their effect is fairly obvious: the more often a chant is repeated, the better it is memorized (Whitehouse 2000). The two extremes of this 'temporal distribution' are represented, on the one hand, by initiation chants that are performed only once for any particular age group and, on the other, by the shamanic hunting chants that some Aguarana repeat daily.

Instead, I focus primarily on rules of distribution. Just as with rules of occurrence, the distribution of ritual chants forms a continuum. At one end, there are chants that are extremely widespread within a given population, for instance, the Wayana's maipuli chants, which are known to all participants in maraké rituals (virtually the entire population), or the Ingarikó's alleluia chants, which are distributed throughout the millenarian community. The form or formalized content of these chants varies little over time or across the population. One of the consequences of this large-scale spatial stability is the chants' relatively limited complexity and/or limited length (which amounts to the same thing). As described above, the Wayana's maipuli chants are limited to the repetition of stereotypical formulas within a standard melodic structure, while alleluia chants, which are supposed to be transmitted word for word and ideally without improvisation (something we shall return to), consist of a few lines endlessly repeated. Azevedo de Abreu (2004: 85-86) provides one fairly typical example:

The young girls are praying, Father

Help them, Father

The young girls are learning to talk, Father

The young girls are sloughing their skin, Father

Listen to them, Father

Neither the maipuli nor the alleluia chants are taught outside of the ritual context in which they occur-that of a collective ceremony. This is typical of one end of the aforementioned continuum, which is characterized by wide distribution, short and easily remembered chants, and the absence of dedicated learning procedures. At the other end of the continuum, we find narrow distribution, along with we might call ritual 'expertise' and the transmission of complex content (long chants and/or a wide repertoire of medium-length chants). These chants are typically transmitted in dyadic master-apprentice relations and are frequently inaccessible to non-specialists; for instance, the patient in 
a healing ceremony will often understand very little of the chants' content. In other words, such chants cannot be transmitted outside of the institution that codifies the master-apprentice relationship.

The kalawu chants sung during Wayana initiation rituals are a classic example of this end of the continuum. The kalawu is composed of a series of 13 chants that must be sung in the correct order. Chapuis and Rivière's (2003) transcription of one such series contains 1,300 lines, and its recitation takes several hours. Hurault (1968: 122) explains that kalawu are sung "in a secret language unknown to the Wayana, which contains some Wayana words that have been inverted or altered by the interpolation of extraneous syllables, but much of which is probably borrowed from now extinct languages. It takes several months to learn this language and how to recite the chants, and this training process is quite separate from that of a shaman." Narrow distribution, long inaccessible chants, and dedicated learning procedures are all characteristic of this end of the oral continuum.

Coshoiti shamanic chants are another example of this end of the continuum. They are restricted to Sharanahua shamans, who must learn a large repertoire of not overly long but highly complex chants. This repertoire is transmitted by a shamanic master during a period of initiation that lasts several months, throughout which apprentices are isolated from wider society, abstain from sexual relations, follow strict dietary restrictions, and ingest a long list of toxic and hallucinogenic substances. Finally, the techniques of lexical substitution discussed above, coupled with a rapid and barely audible recitation, mean that the performance of these chants in a therapeutic context corresponds to a form of speech act that has all the trappings of communication except the deciphering of content (Déléage 2009b). Taken together, this means that there is practically no chance of indirect, contextual transmission of such chants (Buchillet 1983; Cesarino de Niemeyer 2008).

The clustering of characteristics at either end of the continuum is not, of course, absolute. So in a context of widespread distribution of relatively short chants, we can also find explicit rules governing their transmission. Particular performances will ostensibly be aimed at inculcating initiates, and the transmission of magical spells in Amazonia is one clear example of this. These spells-used to cure minor ailments, help with the hunt, promote plant growth, or seduce a partner-are transmitted via explicitly pedagogical relations. For instance, if an Aguarana from the north Peruvian Amazon wishes to learn magical spells (anen), he must ask an elder to transmit part of his repertoire to him. The latter will likely ask for a payment, and then ask his disciple to isolate himself for a certain period of time, abstain from sexual relations, and follow dietary restrictions. The elder will then make him ingest tobacco juice and transmit the anen, which he can use, for example, to attract prey, as Brown (1985: 82-83) documents: 
The spider monkeys come

The spider monkeys come

From that hill they come

The spider monkeys come

With their stiff children they come

Without seeing me they come

From this hill they come

From that hill, too, they come

Sons, sons

Do you speak to spoil my luck?

Spoiling my luck speak you thus?

You speak to attract spider monkey

You speak to attract

I will shoot the spider monkey

High, high, I will shoot

High, high, I will shoot

Turning, turning, I twist poison onto the dart

Turning, turning, I twist poison onto the dart

This monkey I will shoot

High, high, I will lift it

Like manioc pierced

High, high, I will lift it

I will shoot to its wampa fruits

I will shoot to its wampa fruits

Piercingly I will shoot

Piercingly I will shoot

I go, never missing the spider monkey

I go, never missing the spider monkey

What immediately strikes the reader is that the language used is highly formalized: it employs a regular melodic structure and makes use of repetition and parallelism, as well as obfuscating lexical substitution (e.g., "wampa fruits" represent monkey guts). Such spells are known to most Aguarana, but women tend to memorize horticultural spells, while men specialize in hunting spells. Similar traditions are present among Jivaro- and Candoshi-speaking people (Descola 1996; Surrallés 2003), among the Ayoreo (Bessire 2011), the Wayana (de Goeje 1955), the Akuriyó (Jara 1996), the Pemon (Armellada 1972; KochGrünberg [1924] 1982), and many other Amazonian groups.

The broad distribution of such spells is linked to their limited discursive content and relative clarity. Nonetheless, the combination of wide distribution and an institutionalized learning process has one significant effect: when these spells are uttered outside of a teaching context-for instance, when an Aguarana hunter uses them to attract game-they are always masked or hidden. Once learned, anen are uttered only when the spellcaster is alone, and 
are often recited mentally or even whistled. There is, in any case, no room for indirect transmission outside of the dyadic teaching context. Anen can be taught only in direct, ritualized fashion. They can be learned from many different elders, but this requires time and money. Eventually, some Achuar may know several hundred spells by heart, and it is only then that they themselves become elders and can transmit their knowledge to younger generations (Taylor and Chau 1983: 92).

Widely distributed chants that are not transmitted in formal contexts are also susceptible to such temporal variability. It takes time to learn a large number of ritual discourses by indirect transmission. This is what we might call the Barth-Houseman hypothesis: in initiation rituals, where transmission and performance are one and the same thing, it is not novices but rather young initiates who internalize ritual procedures, including discourses. Indeed, the actual process of initiation is scarcely an ideal learning context for the terrorized, brutalized, and exhausted novices. Once initiated, however, the ritual offer is much more easily assimilable (Barth 2002; Houseman 2002). In other words, the more one participates in such collective rituals, the more knowledge one acquires, the more discourses one learns, and the more one belongs to a select slice of the population-one in which the distribution of discourses becomes more and more narrow. This allows us to understand how it is possible to shift from one end to the other by gradually increasing the unequal distribution of ritual knowledge.

\section{Authority and Transmission in Ritual Chants}

This brings us to the following questions: Why, for a given ritual, must some discourses be memorized in one way rather than in another? Why do some discourses demand such fidelity of transmission that they come to be structured by a series of stabilization procedures? And why do some discourses call for as wide a distribution as possible while others are reserved for an elite group of experts? Part of the response to these questions lies in the simple fact that all ritual discourses are transmitted in the name of a particular form of authority (Boyer 1990; Sperber 1996: 107-135). As we will see, singing a ritual chant is always quoting: quoting a teacher, an ancestral being, an entity that appeared during a vision, or a prophet. And all these 'persons' are the authorities of the ritual chants. Their power, experience, and knowledge are the guarantee of the truth of the discourse and the efficacy of its utterance, and their authority partially legitimizes the need for repetition. The nature of the authority in question also determines the need for faithful transmission and reproduction. And it is always in the name of a particular authority that different modes of transmission, distribution, and performance are deemed legitimate. In other words, 
from the point of view of the ritual performer, it is authority that stabilizes an institution and its content (although this causal link is, of course, only partially determined). In what follows, I explore the links between three distinct types of authority-human, mythical, and visionary (each of which is associated with a specific discursive genre)-and the different ways in which the transmission of ritual chants is institutionalized.

The first type of authority involved in fixing ritual transmission is human authority. This type is familiar to anthropologists in the field. The stock and far too general question of why one's informant participates in a given ritual is often met with somewhat evasive responses along the lines of "Because that's what everybody does," "Because that's what my father, mother, grandparents, etc., taught me to do," "Because if I don't, I will be punished in such and such a manner," or finally "Because that's our tradition." Such responses are usually proffered by non-specialists, but even ritual experts sometimes dismiss the importunate anthropologist in this way: "Because that's how my master taught me to do it." These brusque appeals to human authority occur only when a curious outsider asks the sort of question that normally goes unasked. Such responses are more or less spontaneous and are not transmitted as such. They represent a fairly minimal and generalized form of reflexivity vis-à-vis the ritual, but they do not span the gamut of potential appeals to authority. All the ritual discourses discussed so far appeal at times to elementary forms of authority to legitimize their modes of transmission, but it is only maipuli chants that exclusively invoke this form of authority.

This human form of authority can be supplemented and complicated in various ways, according to the organizational structure of the society in question. Unfortunately, we can only address this extremely anthropologically interesting question in passing. We saw that Jivaro spells were characterized by a particular social distribution. Among the Achuar, ánent "are transmitted through consanguineal and/or affinal links, along strict sexual lines," normally, "from mother-in-law or mother to daughter-in-law or daughter; from father-in-law/ father to son-in-law/son; and from elder brother-in-law to younger brother-inlaw" (Taylor and Chau 1983: 92). Another example concerns chiefly discourses among the Kuikuro of the Upper-Xingu. They combine different sequences of fixed fomulae, regulated by a specific prosody, and are uttered in various ritual contexts. They are also transmitted only from chief to would-be chief along male consanguineal lines, and they must be paid for (Franchetto 2000). The situation is even more complicated when it concerns the ritual transmission of particular prerogatives, ceremonial objects, and discourses that must not leave their clan of origin and are passed from father to son. In Amazonia, we find this sort of clan distribution of ritual discourses (linked to different origin myths) in the collective rituals of the Upper Rio Negro (Hugh-Jones 2010). This form of social distribution of authority often leads to conflict, competition, and even virtual 
arms races between different clans and their proprietary knowledge. Such social complexification of human authority is also relevant to the anthropologist insofar as she or he is always imbricated in these relational webs. The transcription, translation, and publication of ritual discourses from oral societies runs up against knotty questions of intellectual property rights, which were initially analyzed in societies where the distribution of knowledge was uneven, but should be addressed in all Amazonian societies-even those where distribution was quite even (Carneiro da Cunha 2009; Déléage 2011; de Vienne and Allard 2005).

The second type of authority legitimizing the transmission of ritual chants is to be found in mythical narratives. In Amazonia, humans are generally believed to have inherited their ritual chants (and sometimes other elements of the ritual panoply) from mythical animals. For instance, the origin of kalawu chants is known to all Wayana, and there are several recorded versions of their origin myth. It explains how a man went hunting and, having got lost in the jungle, met several different animals that transmitted different elements of the maraké initiation ritual to him. The kalawu chant was taught to him by a cacique songbird: "Once upon a time, it was pajakwa the yellow-rumped cacique who sang the kalawu during his children's maraké initiation ceremonies. Alalikama was the first man to learn the kalawu. He got lost in the jungle and heard the cacique singing the kalawu to its children. And so he learned it. This is how the kalawu appeared among the Wayana. This why the Wayana organize the maraké for their children, like the cacique did for its children" (Camargo and Kulijaman, n.d.).

Sharanahua coshoiti chants also feature in a mythical narrative, which describes how the chants were originally created by anacondas, and there is also a myth describing the way that spider monkeys transmitted hunting spells to the Aguaruna (Brown 1985: 75; Déléage 2009a: 215). There are numerous other examples of such mythical narratives. In each case, the legitimacy of discursive transmission is dependent on the originating authority of a mythical ancestor-in other words, not on contemporary caciques, anacondas, or spider monkeys, but on their ancestors who could speak and had all the trappings of humanity. Thus, the authority of ritual discourse is derived not only from a vague appeal to tradition or from the prestige of a particular member of society, but also from a mythical ancestor. If we take these narratives at their word, today's ritual discourses are little more than reproductions of the original discourses transmitted to humans by caciques, anacondas, and spider monkeys in some distant mythical time. The combination of human and supernatural sources of authority ought to encourage people to faithfully preserve such chants and so increase their spatio-temporal stability.

The third form of authority generally complements the first two. It is normally associated with shamans, in particular with vision narratives. It is not enough for a shaman simply to appeal to some mythical authority; he must 
legitimize his chants by entering into direct contact with supernatural entities, often called 'masters', who teach the chants to him. To this end, he must give a vision narrative of their transmission. The following summarizes a vision narrative of the Sharanahua shaman Picha (Déléage 2009a):

The "master" spirits come to me one after the other. I see them come, see them come down. Their body paintings come down to me and I can do nothing. It is the power of ayahuasca that comes down to me, and I can do nothing. I also see the flowers of plant spirits come to me. That is how it is. Then the stranger's ladder appears, the metal ladder. The master spirits jump down it. Together they look like a fishing net, coming down from on high. It falls down and covers me. That is how I see them come. They are many and their tongues flicker in and out of their mouths, making a sound like "siro, siro." The anaconda affects my thoughts. In his mouth is a wad of tobacco that blackens his teeth. He grabs my feet and blows on me. That is how I see them come, with many others. Only the anaconda makes my body feel like a ball. He grabs my throat and spins me round. I see the master spirits come, singing " $y a, y a, y a$." Anybody else would weep if he saw them like that. Bairo would weep. Then the great radio begins to work, going " $t i$, $t i$." I hear the great boat's radio and many other master spirits appear. They begin to sing for me: "Bato yari iquicai, uayari icapu." I have heard them singing like that many times.

Such narratives are remarkably homogeneous across the Amazon region. We find the same generalized ontological slippage from a multiplicity of richly decorated humanoid spirits to a series of individual incarnations of animals or plants; the same more or less metaphorical usage of white men's objects (vehicles, radios, etc.); and often the same three narrative stages (Arevalo Valera 1986; Chaumeil 1983: 33-43; Descola 1996; Gallois 1996; Kopenawa and Albert 2010: 84-89; Langdon 2002; Payaguaje 1990). The first stage describes an attack on the novice shaman. This attack can take many forms (being shot with arrows, devoured, or poisoned), but it is always the work of supernatural entities. The second stage sees the creation of a social relationship between the novice and one or more supernatural entities. This relationship is based on everyday social relations and can also take many forms: marriage, adoption, domestication, and so forth. In the third stage, the supernatural entities transmit power, knowledge, ceremonial objects, or ritual chants to the novice. He then becomes a shaman. Picha's narrative contains only the first and the third of these stages: first, we see him attacked by the anaconda, and then the master spirits teach him their chants.

The novice must listen carefully to such narratives, for they describe the horizon of what he can experience during the physical privations and sufferings his master will inflict upon him. The narrative will then transform into a series of dreamed or hallucinated events. This is how novices will make 
contact with the supernatural. It is often in such altered mental states that they first begin to learn shamanic chants. Yet in any case, such experiences are a far more direct 'proof' of the origin of these chants than mere mythical narratives ever are. This form of authority is necessarily linked to dedicated teaching institutions, where learning and performance are decoupled from one another. It is most frequently present in the process of becoming a shaman, but we also find it, albeit in diluted form, in the transmission of spells. This supernatural authority overlays the human authority of the shaman who instructs the novice and who 'really' teaches him the shamanic chants. This form of authoritative duplication is very common in Amazonian shamanism (Déléage 2009b), and the vision narrative itself frequently models the descriptions of shaman-master spirit interactions on the pedagogical relationship between master and disciple.

This visionary authority, which is always more or less directly derived from pre-existing narratives of mythical authority, plays an important role in determining the form of transmission it employs. It typically encourages the development of expertise and long, inaccessible chants that are transmitted by means of dedicated dyadic teaching institutions. Visionary authority is then logically associated with one end of the distribution continuum, where expertise and doctrinal complexity go hand in hand.

The transmission of ritual chants is, then, always legitimized by reference to a form of authority embodied in a range of different entities: humans, ancestors, or supernatural spirits. This reference is transmitted through specific discursive genres, such as myths or vision narratives, but also via everyday speech acts. These epistemological discourses describe entities who are conceived of as the original owners of the chants and are thus perceived as prime movers in the chain of transmission (Déléage 2009a). The different forms of authority play an important role both in stabilizing ritual chants and in determining the institutional mode of transmission. In the next section, we explore what happens when these traditional forms of authority are challenged.

\section{Ritual Innovation}

The particularly complex nature of prophetic authority provides us with an ideal opportunity to examine the usefulness of the analytical tools developed in the epidemiological approach to ritual discourse. One striking example, founded in the 1880s by the prophet Pichiwön, is the alleluia cult, the only Amerindian messianic movement to have endured within the Amazon region. This particular cultural phenomenon, which broke with traditional ritual processes and semantic content, but which nonetheless had to find a way to prosper and stabilize, can be thought of as an experimental crucible for the approach outlined above. 
Pichiwön, a Macuxi who had probably spent time near an Anglican mission in northern British Guyana, had a divine vision. In the 1960s, Henry Grant, a Patamona ritual specialist, recounted his memory of Pichiwön's vision to the anthropologist Butt Colson (1971). According to Grant, Pichiwön traveled to England with two priests. While he studied and thought things over, he had a vision in which God spoke to him. After a long conversation, God showed him the beauties of Paradise promised to the Indians and gave Pichiwön a perfumed book full of writings, including the alleluia. God ordered him to hide it from the English priests. When Pichiwön returned home, he taught his people the alleluia dances and chants. After his death, one of his disciples, Abel, disseminated Pichiwön's prophecy and ritual among the Kapon (see ibid.: 32-48 for the complete account).

The alleluia chants forecast that the Indians would soon become immortal "White Men," rich in manufactured goods, and that one way to speed up the process was to organize alleluia ceremonies like the ones described in the "Bible" God had given to Pichiwön. The chants had to be performed in a ritual context very similar to traditional Macuxi ceremonies (with their manioc beer and ritual dances), but they also incorporated several elements of Christian ritual, including regular kneeling and calling the building a "church." The language used in the chants also made liberal use of foreign loanwords, such as alleluia and aypilipin-a corruption of "I believe in him" (Azevedo de Abreu 2004).

Pichiwön's vision narrative and new liturgy spread like wildfire across the region's principal commercial networks. They touched the Pemon and the Kapon $^{3}$ in their entirety and stabilized among the latter. In the mid-twentieth century, when Kenswil (1946) carried out a study of the Akawaio, part of the Kapon group, he was swift to pick up on the genealogical nomenclature reaching forward from the founder: Pichiwön's alleluia was first transmitted to Abel, then to Christ, then Queen Mule, and finally to Awaima. A few year's later, Audrey Butt (1960: 89) was even able to contrast an idealized version of this transmission, as recounted by an Akawaio ritual specialist named John Charlie, with the 'real' version, which she reconstituted from different interviews (see fig. 2).

The prophet Pichiwön's founding vision cleaved to visionary standards: he claimed that the chants and ritual apparatus had been directly revealed to him by God. In so doing, he denied any human element in the process of transmission, although we could of course point to the similarities with traditional collective ritual dances and the continuities with other short-lived prophetic movements that emerged in the region from the 1830s onward (Azevedo de Abreu 2004). The originality of Pichiwön's message (and most likely of the other prophetic movements) lies in the new eschatological ends to which these borrowed and agglutinated pieces of ritual are put-to wit, the idea that ritual 


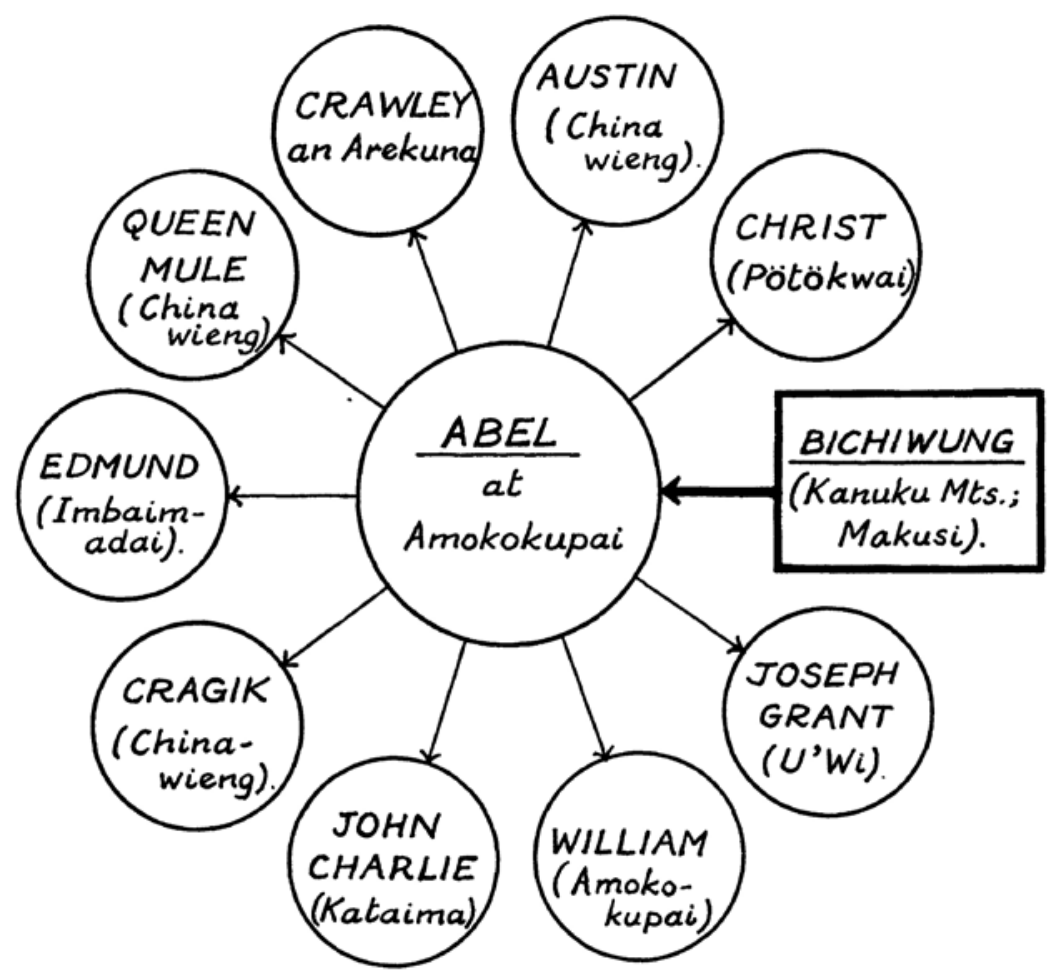

FigURE 2: John Charlie's idealized version of the transmission of the alleluia. Source: Butt (1960: 89). Courtesy of L'Homme.

participation will guarantee salvation, and that when the Messiah comes, he will transform the Indians into immortal White Men. It follows that Pichiwön's vision narrative is just as important to the spread of the religion as the ritual liturgy and chants.

From the point of view of its followers, the authority of the religion's ritual chants derives from God, but also from Pichiwön. So while Pichiwön's relationship to the alleluia chants was one of shamanic authority, his followers were more in a relationship of mythical authority, with his vision narrative replacing the standard mythical narrative. For these followers, the alleluia chants legitimating authority involved neither a mythical ancestor nor a supernatural entity with whom one could enter into contact, but instead a complex form of authority combining God's visionary transmission of the song to Pichiwön and Pichiwön's subsequent retransmission to his followers in the form of a vision narrative. This hybrid prophetic authority thus legitimized the movement's 
ritual prayers via its appearance in the vision narrative as a one-off supernatural transmission. Unlike shamanic vision narratives, which are transmitted so that they can be verified by others who undergo the same experience, this original act of transmission could not be replicated by Pichiwön's followers. While he was alive, his prophetic narratives could only be quoted.

From a historical point of view, the alleluia movement is fairly exceptional in that it allows an analysis of the degrees of variation in the two elements that principally interest us here: Pichiwön's vision narrative and the chants themselves. Because they are relatively short, highly formalized, and incessantly repeated, alleluia chants show little variation over the course of their history; indeed, the alleluia refrain seems to have been stable for the last 150 years (Azevedo de Abreu 2004: 23). In contrast, Pichiwön’s vision narrative appears never to have been the object of formal transmission. Among some groups, especially the Patamona, it has remained relatively stable (Butt Colson 1971; Whitehead 2002: 152), but elsewhere it has undergone processes of transformation that have led to a series of redefinitions of the legitimating supernatural entity.

The movement rapidly acquired a particular morphology, with Pichiwön's followers separating into two groups after his death: ritual specialists and the lay masses. The ritual apparatus was handed down from specialist to specialist along shamanic lines: each new specialist had a similar visionary experience to Pichiwön in which he interacted with supernatural entities. This is evident in the vision narratives of the Akawaio Abel and Christ, which have been written down. Each new specialist 'disquoted' the prophetic visionary narrative, roughly keeping its content while substituting his own person as its authoritative source. Some of them also acquired new chants, which they then taught to the masses. The distinction between ritual specialists and followers was thus not a question of how many chants they knew, but of whether they had visionary access to supernatural entities. Nevertheless, Pichiwön's original vision narrative remained in circulation, and his successors were careful to present themselves as having such visionary experiences.

The alleluia movement died out fairly rapidly among the Pemon, only to re-emerge in a new context-that of the San Miguel movement in the 1970s (Andrello 1999). The similarities between the liturgical apparatus and discourses of these two movements are striking. However, the chants' legitimating authority no longer resided in Pichiwön's vision narrative or in its visionary confirmation by a ritual specialist; instead, it appealed to a new narrative. A Pemon woman named Lucencia entered into contact with the "Archangel San Miguel," who gave her a message very similar to Pichiwön's and also taught her new chants and ritual practices. Thus, Pichiwön's alleluia chants were now legitimized by a new vision narrative, which disquoted and simultaneously occluded the original vision (Thomas 1976: 39). 
A quite different form of authoritative transformation occurred in the 1990s among a Brazilian Kapon group called the Ingarikó. They appeared to have completely forgotten Pichiwön's original vision narrative and instead traced the genealogy of the alleluia chants and rituals back to "the time of the ancestors," that is, to a quasi-mythical past. In other words, by the end of the late twentieth century, the corrosive effect of memory had reduced Pichiwön's prophetic authority to a mythical one (Azevedo de Abreu 2004: 95).

We can see that prophetic authority differs from mythical and visionary authority in that it establishes a clear separation between the original act of transmission (from supernatural entity to prophet) and subsequent acts of transmission (from prophet to followers). When the followers sing the ritual chants, they are not repeating the words of mythical ancestors or supernatural entities, but those of the prophet. This form of authority has two notable and distinct characteristics: it aims to proselytize, and it is relatively unstable. This instability is evident in the possibility of reconversion into visionary (as with the San Miguel movement) or mythical (as with the Ingarikó) forms of authority. These latter forms of authority appear to be more stable. Moreover, insofar as prophetic authority is necessarily novel, it must persuade its followers of its efficacy and relevance through an expansion process. This means that the ritual institution it legitimizes tends toward the end of the spectrum characterized by a wide distribution of relatively short and semantically accessible chants. As such, these chants stabilize relatively easily, as we have seen with the alleluia chants.

Despite this, Pichiwön was not blind to the redoubtable efficacy of one particular technique deployed by his Christian rivals in the battle for souls: the use of writing to translate, print, and disseminate their own chants (Butt Colson 1998: 12). Like many other Amazonian shamans, Pichiwön understood that books helped to increase the authority and stability of the discourses they contained. This explains not only why his vision narrative contained a sequence where God gave him a "Bible" containing the alleluia chants (Déléage 2010b), but also why some alleluia rituals use techniques of inscription similar to Teko 'rosary beads'.

By way of example, in the early twentieth century, William, an Akawaio alleluia specialist, showed the missionary Cuthbert Cary-Elwes a document that he considered just as important as his rival's own texts (see fig. 3). As Cary-Elwes recounted (cited in Butt Colson 1998: 76-77):

The drawings at the top, they told me, were the boats in which all the good things they were expecting are going to be brought. Then William, taking the paper in his left hand, pointed with his right to each figure, one after the other, beginning with the one at the right-hand top corner, and explained what each was meant to represent. 'This', he said, 'is a boat full of gunsthis is a boat full of gunpowder-this is a boat full of gun-caps-this is a boat full of shot-this is a boat full of knives-this is a boat full of cloth', etc., etc., right on to the end. 


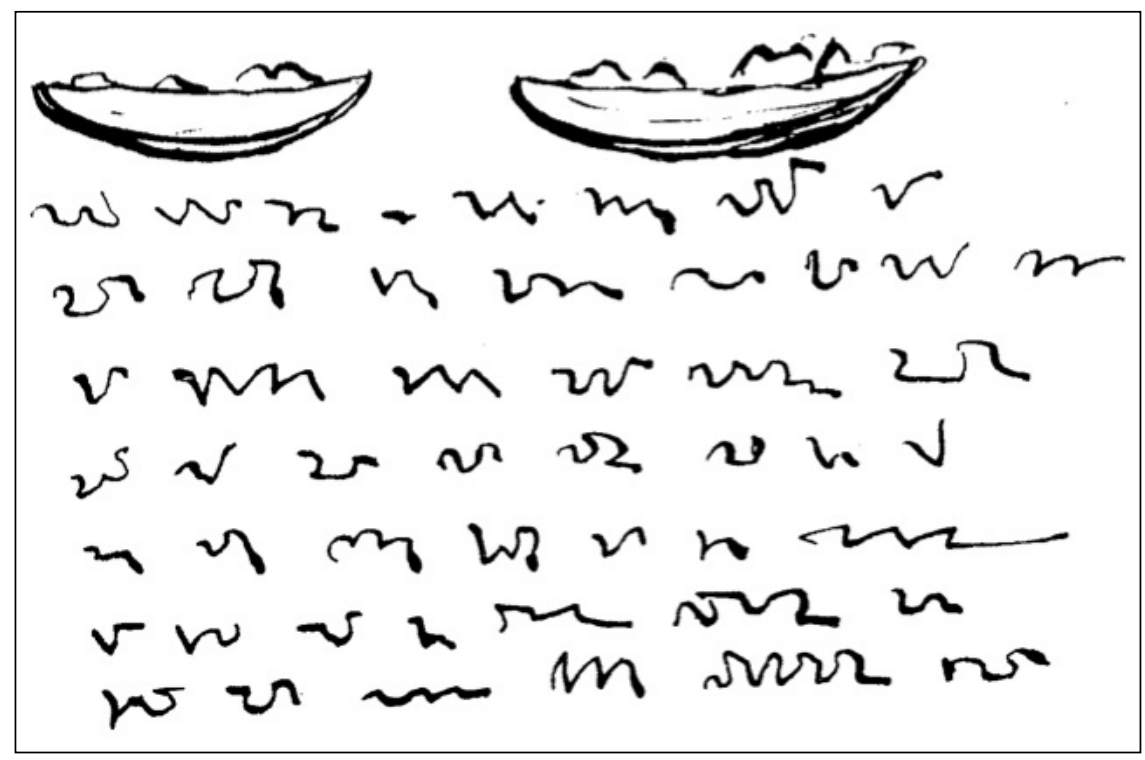

Figure 3: Alleluia document. Source: Butt Colson (1998: 76). Courtesy of L'Homme.

Nearly a century later, Susan Staats (2003) discovered that William was merely reciting one particular chant, known as the maiyin, which is used to close alleluia ceremonies. These highly parallelistic chants are slightly longer than normal prayers and are composed of two endlessly repeated segments, interspersed with long lists of names, as in the following example (ibid.: 49):
Apparel's throne
Bead's throne
Lap cloth's throne
Knive's throne
Axe's throne
Gunpowder's throne
Shotgun shell's throne
Cap's throne
Shotgun's throne

William's document recorded in the form of wavy lines the correct order of the variable elements in the maiyin. Fixed elements, such as the 'boat', which later became a 'throne', were marked only the first two times they were used. This can be thought of as an aniconic version of Teko memory strings: the chants' variable elements are 'represented' by similar-looking figures, and it is only the correct order of the chants that is given material form, just as with prayer beads. William, then, pulled off a double coup: on the one hand, he 
appropriated the prestige and authority of the missionaries' texts by borrowing the idea-and to a certain extent the form-of their books; on the other, he increased the chants' ritual stability by employing a new inscription technique.

In the 1970s, the San Miguel movement, an offspring of the alleluia movement, resolved its own problems of dissemination and maximal stabilization by deploying another technological innovation: a form of cartographic inscription. The 'map of the prophet' that San Miguel revealed to Lucencia (see fig. 4) depicted the obstacles along the path to Paradise and the liturgical techniques used to surmount them (Thomas 1976: 42-49). And its ritual prayers, which were very similar to alleluia chants, were disseminated in 'high fidelity' using audio cassettes (ibid.: 21).

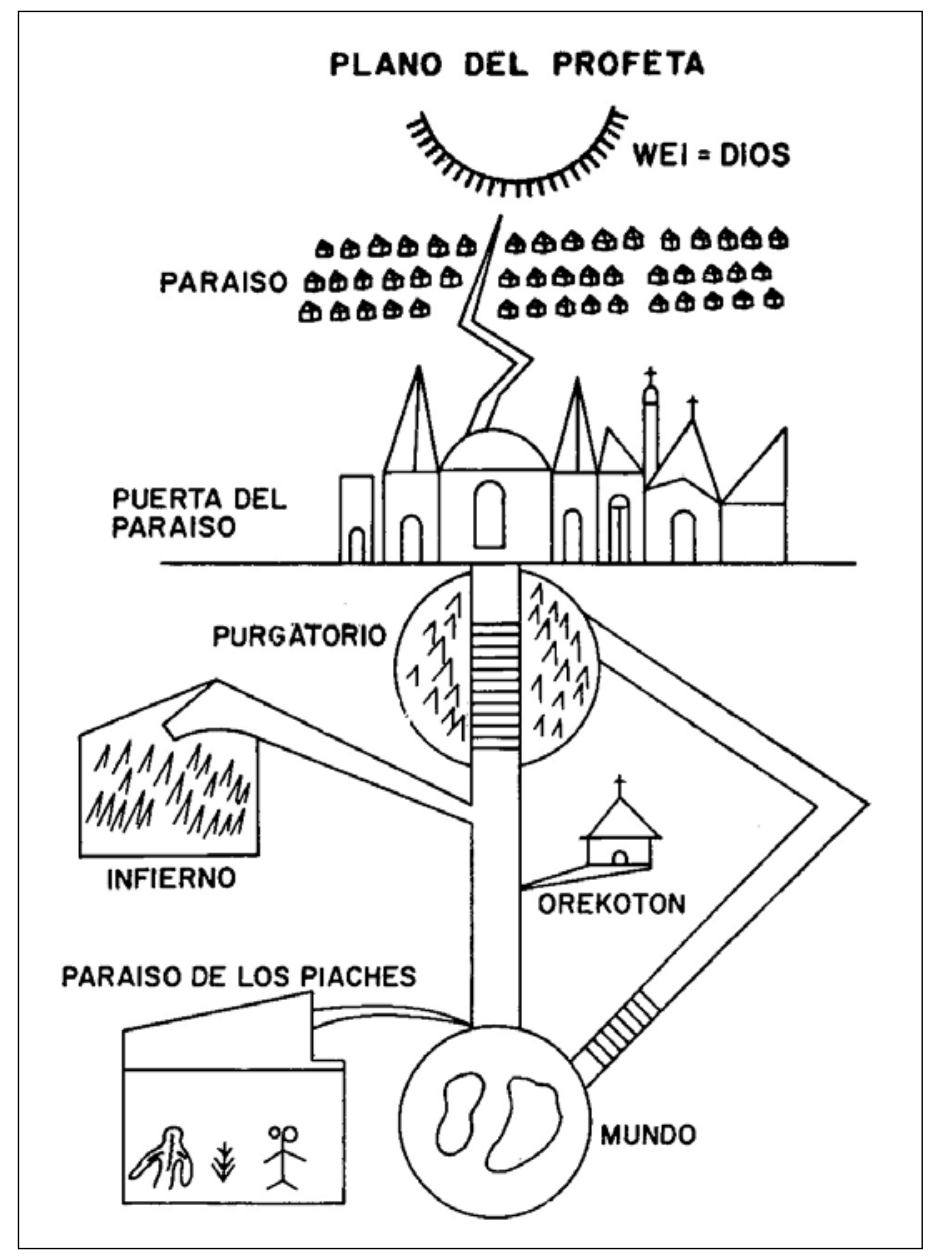

FigurE 4: The map of the prophet. Source: Thomas (1976: 43). Courtesy of L'Homme. 


\section{Conclusion}

This analysis of a range of Amazonian traditions has endeavored to show the usefulness of an epidemiological approach to ritual discourse. Unlike essentialist approaches to the question, it does not seek to draw up a list of the inherent properties of ritual chants. And unlike classificatory approaches, it eschews ideal types of initiation rituals, shamanism, and prophetic movements. Instead, it uses a comparative perspective to explore the idea that ritual traditions are composed of numerous heterogeneous elements with varying degrees of stability and are subject to a range of external factors. It then identifies a series of universal factors (stabilization techniques, institutional rules, and modes of authority) that explain at least partially why particular chants have been disseminated and stabilized in one form rather than another.

This shift from the generic study of ritual chants to the examination of specific but universal factors holds out the possibility of a new approach to anthropology-one that breaks once and for all with ongoing and ultimately fruitless attempts to define and circumscribe terms such as 'culture', 'tradition', and 'ritual'. These different universal factors-which allow for the stabilization of ritual discourses and their modes of transmission, and which underpin the dynamics of dissemination and transformation of broader cultural traditionsare indeed impervious to the traditional cultural and categorical distinctions employed in anthropology. Their analysis is just beginning.

\section{Acknowledgments}

This article appeared originally in French as "Transmission et stabilisation des chants rituels" in L'Homme 203-204 (2012): 103-137. Minor stylistic changes have been made to avoid misunderstandings.

Pierre Déléage is a researcher at the Laboratoire d'anthropologie sociale (Centre national de la recherche scientifique, Collège de France, Ecole des hautes études en sciences sociales) in Paris. E-mail: pierre.deleage@college-de-france.fr 


\section{Notes}

1. Very short narrative sequences can also demonstrate a high degree of stability across both space and time. The Sharanahua myth quoted above is identical to a narrative from the Ecuadorian Quichua (Orr and Hudelson 1971) and to Tupi-Guarani narratives published in 1575 by André Thevet, in 1914 by Curt Nimuendajú, in 1959 by León Cadogan, and in 1972 by Pierre Grenand.

2. Procedural memory allows for the acquisition of automatisms that gradually become unconscious, while schematic memory enables the reconstruction of a succession of narrative episodes. Verbal memory encodes the sonic form taken by a discourse, that is, the actual sounds.

3. The Kapon language and culture family includes the Akawaio, Patamona, Waica, Ingarikó, Serekong, and Eremagok. The Pemon includes the Arekuna, Taurepang, Kamarakoto, and Macuxi.

\section{References}

Albert, Bruce, and Alcida Rita Ramos, eds. 2002. Pacificando o branco: Cosmologias do contato no Norte-Amazônico [Pacifying the white man: Cosmologies of contact in North Amazon]. São Paulo: Editora UNESP.

Andrello, Geraldo. 1999. "Profetas e pregadores: A conversão taurepáng à religião do Sétimo Dia” [Prophets and preachers: Taurepang conversion to Seventh-day Adventism]. In Transformando os Deuses: Os Múltiplos Sentidos da Conversão entre os Povos Indigenas no Brasil [Transforming the gods: The multiple senses of conversion among the indigenous peoples in Brazil], ed. Robin M. Wright, 285-308. Campinas: UNICAMP.

Arevalo Valera, G. 1986. "El ayahuasca y el curandero Shipibo-Conibo" [Ayahuasca and the Shipibo-Conibo healer]. América Indígena 46 (1): 147-151.

Armellada, Cesáreo de. 1972. Pemontón Taremurú [Magical invocations of the Pemon Indians]. Caracas: Universidad Católica Andrés Bello.

Assmann, Jan. 1992. Das kulturelle Gedächtnis: Schrift, Erinnerung und politische Identität in frühen Hochkulturen [Cultural memory: Writing, remembering and political identity in early advanced cultures]. Munich: C. H. Beck.

Azevedo de Abreu, Stela. 2004. Aleluia e o banco de luz [Hallelujah and the bank of light]. Campinas: Centro de Memória Unicamp.

Barth, Fredrik. 2002. "Review of Arguments and Icons: Divergent Modes of Religiosity (Harvey Whitehouse, Oxford Univ. Press, 2000)." Journal of Ritual Studies 16 (2): 14-17.

Bartlett, Frederic C. 1932. Remembering: A Study in Experimental and Social Psychology. Cambridge: Cambridge University Press.

Beaudet, Jean-Michel. 1983. "Les orchestres de clarinettes tule des Wayãpi du Haut-Oyapock (Guyane française)" [The Tule clarinet orchestras of the Wayãpi of Haut-Oyapock (French Guyana)]. PhD diss., Université Paris Nanterre. 
Beaudet, Jean-Michel. 1997. Souffles d'Amazonie: Les orchestres tule des Wayãpi [Breaths of the Amazon: The Tule orchestras of the Wayãpi]. Nanterre: Société d'ethnologie.

Beaudet, Jean-Michel. 2010. Nous danserons jusqu'à l'aube: Essai d'ethnologie mouvementée en Amazonie [We will dance until dawn: Essay on turbulent ethnology in the Amazon]. Paris: Éditions du CTHS.

Bessire, Lucas. 2011. "Ujnarone Chosite: Ritual Poesis, Curing Chants and Becoming Ayoreo in the Gran Chaco.” Journal de la Société des Américanistes 97 (1): 259-289.

Bloch, Maurice. 1974. "Symbols, Song, Dance and Features of Articulation: Is Religion an Extreme Form of Traditional Authority?" European Journal of Sociology 15 (1): 55-81.

Boyer, Pascal. 1990. Tradition as Truth and Communication: A Cognitive Description of Traditional Discourse. Cambridge: Cambridge University Press.

Brown, Michel F. 1985. Tsewa's Gift: Magic and Meaning in an Amazonian Society. Washington, DC: Smithsonian Institution Press.

Buchillet, Dominique. 1983. "Maladie et mémoire des origines chez les Desana du Uaupès” [Illness and memory of origins among the Desana of Uaupès]. PhD diss., Université Paris Nanterre.

Butt, Audrey J. 1960. “The Birth of a Religion.” Journal of the Royal Anthropological Institute of Great Britain and Ireland 90 (1): 66-106.

Butt Colson, Audrey J. 1971. "Hallelujah among the Patamona Indians.” Antropológica 28: 25-58.

Butt Colson, Audrey J. 1998. Fr. Cary-Elwes S.J. and the Alleluia Indians. Georgetown: University of Guyana.

Camargo, Eliane, and Mataliwa Kulijaman. n.d. "Le monde musical et mythique des Wayana de Guyane française: Le fonds sonore de Jean-Marcel Hurault” [The mythical and musical world of the Wayana of French Guyana: Jean-Marcel Hurault's sound archive]. Unpublished manuscript.

Carneiro da Cunha, Manuela. 2009. Cultura com aspas e outros ensaios de antropologia [Culture with quotes and other anthropological essays]. São Paulo: Cosac Naify.

Cesarino de Niemeyer, Pedro. 2008. “Oniska: A poética da morte e do mundo entre os Marubo da Amazônia occidental” [Oniska: The poetics of death and the world among the Marubo of western Amazonia]. PhD diss., Universidade Federal do Rio de Janeiro.

Cesarino de Niemeyer, Pedro. 2011. “Entre la parole et l'image: Le système mythopoétique marubo" [Between speech and image: The mythopoetic system of the Marubo]. Journal de la Société des Américanistes 97 (1): 223-257.

Chapuis, Jean, and Hervé Rivière. 2003. Wayana eitoponpë: (Une) histoire (orale) des Indiens Wayana [Wayana eitoponpë: (An oral) history of the Wayana Indians]. Matoury: Ibis Rouge.

Chaumeil, Jean-Pierre. 1983. Voir, savoir, pouvoir: Le chamanisme chez les Yagua de l'Amazonie péuvienne [See, know, power: Shamanism among the Yagua of the Peruvian Amazon]. Paris: EHESS. 
de Goeje, Claudius Henry. 1955. Philosophie, initiation et mythes des Indiens de la Guyane et des contrées voisines [Philosophy, initiation, and myths of the Indians of Guyana and neighboring regions]. Paris.

Déléage, Pierre. 2009a. Le chant de l'anaconda: L'apprentissage du chamanisme chez les Sharanahua (Amazonie occidentale) [The song of the anaconda:

Learning to be a shaman among the Sharanahua (Western Amazonia)]. Nanterre: Société d'ethnologie.

Déléage, Pierre. 2009b. "Les savoirs et leurs modes de transmission dans le chamanisme sharanahua" [Knowledge and its modes of transmission in Sharanahua shamanism]. In Paroles en actes [Words in action], ed. Carlo Severi and Julien Bonhomme, 63-85. Paris: L'Herne.

Déléage, Pierre. 2010a. "Mythes et chants rituels chez les Sharanahua.” [Myths and ritual chants among the Sharanahua]. Ateliers d'anthropologie 34. https:// doi.org/10.4000/ateliers.8566.

Déléage, Pierre. 2010b. "Rituels du livre en Amazonie" [Book rituals in the Amazon]. Cahiers des Amériques Latines 63-64: 47-62.

Déléage, Pierre. 2010c. "Une pictographie amazonienne” [An Amazonian pictography]. Gradhiva 12: 176-197.

Déléage, Pierre. 2011. "Les discours du rituel” [Ritual discourses]. Journal de la Société des Américanistes 97 (1): 77-86.

Descola, Philippe. 1996. The Spears of Twilight: Life and Death in the Amazon Jungle. Trans. Janet Lloyd. New York: New Press.

de Vienne, Emmanuel, and Olivier Allard. 2005. "Pour une poignée de dollars? Transmission et patrimonialisation de la culture chez les Trumai du Brésil central" [For a handful of dollars? Transmission and heritage of culture among the Trumai of Central Brazil]. Cahiers des Amériques Latines 48-49: 127-145.

Fausto, Carlos. 2002. "Faire le mythe: Histoire, récit et transformation en Amazonie" [Making the myth: History, narrative, and transformation in the Amazon]. Journal de la Société des Américanistes 88: 69-90.

Fausto, Carlos, Bruna Franchetto, and Tommaso Montagnani. 2011. "Les formes de la mémoire: Art verbal et musique chez les Kuikuro du Haut-Xingu” [The forms of memory: Verbal art and music among the Kuikoro of the UpperXingu]. L'Homme 197: 41-69.

Finnegan, Ruth H. (1977) 1992. Oral Poetry: Its Nature, Significance, and Social Context. Bloomington: Indiana University Press.

Franchetto, Bruna. 2000. "Rencontres rituelles dans le Haut-Xingu: La parole du chef” [Ritual encounters in the Upper-Xingu: The chief's word]. In Les rituels du dialogue [Rituals of dialogue], ed. Aurore Monod-Becquelin and Philippe Erikson, 481-509. Nanterre: Société d'ethnologie.

Gallois, Dominique Tilkin. 1996. "Xamanismo Waiãpi: Nos caminhos invisíveis, a relação $i$-paie” [Waiãpi shamanism: In the invisible paths, the $i$-paie relationship]. In Xamanismo no Brasil: Novas perspectivas [Shamanism in Brazil: New perspectives], ed. Jean Matteson Langdon, 39-74. Florianópolis: UFSC.

Goody, Jack. 1987. The Interface between the Written and the Oral. Cambridge: Cambridge University Press. 
Houseman, Michael. 2002. "Review of Arguments and Icons: Divergent Modes of Religiosity (Harvey Whitehouse, Oxford Univ. Press, 2000).” Journal of Ritual Studies 16 (2): 18-22.

Hugh-Jones, Stephen. 2010. "Entre l'image et l'écrit: La politique tukano de patrimonialisation en Amazonie" [Between the image and the written word: The Tukano policy of heritage development in the Amazon]. Cahiers des Amériques Latines 63-64: 195-227.

Hurault, Jean. 1968. Les indiens Wayana de la Guyane française: Structure sociale et coutume familiale [The Wayana Indians of French Guyana: Social structure and family custom]. Paris: ORSTOM.

Jara, Fabiola. 1996. El camino del Kumu: Ecología y ritual entre los Akuriyó de Surinam [The path of the Kumu: Ecology and ritual among the Akuriyó of Surinam]. Quito: Abya-Yala.

Kenswil, Frederick W. 1946. Children of the Silence: An Account of the Aboriginal Indians of the Upper Mazaruni River, British Guiana. Georgetown, Guyana: Interior Development Community.

Koch-Grünberg, Theodor. (1924) 1982. Del Roraima al Orinoco [From the Roraima to the Orinoco]. Caracas: Ediciones del Banco central de Venezuela.

Kopenawa, Davi, and Bruce Albert. 2010. La chute du ciel: Paroles d'un chaman yanomami [The fall of the sky: Words of a Yanomami shaman]. Paris: Plon.

Langdon, Esther Jean. 2002. "A tradição narrativa e aprendizagem com yagé (ayahuasca) entre os indios Siona de Colômbia” [Narrative tradition and learning with yagé (ayahuasca) among the Siona Indians of Colombia]. In O uso ritual da ayahuasca [The ritual use of ayahuasca], ed. Beatriz C. Labate and Wladimir S. Araújo, 67-91. São Paulo: FAPESP.

Menezes Bastos, Rafael José de. 2007. "Música nas sociedades indígenas des terras baixas da América do sul" [Music in indigenous societies in the lowlands of South America]. Mana 13 (2): 293-316.

Nagy, Gregory. 1996. Poetry as Performance: Homer and Beyond. Cambridge: Cambridge University Press.

Orr, Carolina D., and Juan E. Hudelson. 1971. Cuillurguna: Cuentos de los Quichuas del Oriente Ecuatoriano [Cuillurguna: Tales of the Quichuas of the Ecuadorian East]. Quito: Houser.

Payaguaje, Fernando. 1990. El bebedor de yaje [The drinker of yaje]. Quito: Vicarito Apostólico de Aguarico.

Severi, Carlo. 2007. Le principe de la chimère: Une anthropologie de la mémoire [The chimera principle: An anthropology of memory]. Paris: Aesthetica.

Smith, Richard C. 1977. "Deliverance from Chaos for a Song: A Social and Religious Interpretation of the Ritual Performance of Amuesha Music.” PhD diss., Cornell University.

Sperber, Dan. 1996. Explaining Culture: A Naturalistic Approach. Oxford: Blackwell. Sperber, Dan, and Lawrence A. Hirschfeld. 2004. "The Cognitive Foundations of Cultural Stability and Diversity.” Trends in Cognitive Science 8 (1): 40-46.

Staats, Susan K. 2003. "Communicative Ideology in Kapon Religious Discourse.” PhD diss., Indiana University. 
Surrallés, Alexandre. 2003. Au coeur du sens: Perception, affectivité, action chez les Candoshi [At the heart of meaning: Perception, affectivity, action among the Candoshi]. Paris: Maison des Sciences de l'Homme.

Taylor, Anne Christine, and Ernesto Chau. 1983. "Jivaroan Magical Songs.” Amerindia 8: 87-128.

Thomas, David J. 1976. "El movimiento religioso de San Miguel entre los Pemon” [The religious movement of San Miguel among the Pemon]. Antropológica 43: $3-52$.

Whitehead, Neil L. 2002. Dark Shamans: Kanaimà and the Poetics of Violent Death. Durham, NC: Duke University Press.

Whitehouse, Harvey. 2000. Arguments and Icons: Divergent Modes of Religiosity. Oxford: Oxford University Press.

Wright, Robin M. 1993. "Pursuing the Spirit: Semantic Construction in Hohodene Kalidzamai Chants for Initiation.” Amerindia 18: 1-40. 